\title{
Discourse and Dissent in the Coverage of Hyderabad Blasts by the Leading Indian English Dailies
}

\author{
Saima Riyaz' ${ }^{1}$ Dr Aaliya Ahmed ${ }^{2}$ \\ 1PhD Scholar, ${ }^{2}$ Senior Assistant Professor \\ 1,2Media Education Research Centre, University of Kashmir, Srinagar, India
}

\begin{abstract}
How to cite this paper: Saima Riyaz | Dr Aaliya Ahmed "Discourse and Dissent in the Coverage of Hyderabad Blasts by the Leading Indian English Dailies" Published in International Journal of Trend in Scientific Research and Development (ijtsrd), ISSN: 24566470, Volume-3 | Issue-3, April 2019, pp. 9-16. http://www.ijtsrd.co $\mathrm{m} /$ papers/ijtsrd216 09.pdf

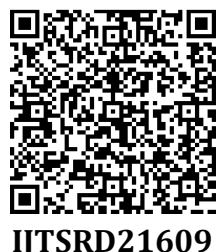

Copyright (c) 2019 by author(s) and International Journal of Trend in Scientific Research and Development Journal. This is an Open Access article distributed under the terms of the Creative Commons

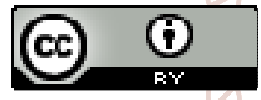
Attribution License (CC BY 4.0) (http://creativecommons.org/licenses/ by $/ 4.0$ )

\section{INTRODUCTION}

Newspapers contain different kinds of information that can be used in various ways - for entertainment, education as well as research. Social and cultural values of a certain place and time are reflected by newspapers. They carry the language structure of certain time and often have unique information that is hard to find anywhere else. The opinion that newspapers are losing their ability to influence politics because of the decrease in circulation is refuted by Greenslade (2011) who explains how newspapers, despite the decline, still influence the political process. The author argues that news acts as a stimulator for broadcasters and bloggers who then respond accordingly. "The material that appears most often in the main current affairs programmes on TV and radio, plus radio phone-in shows, is almost always based on follow-ups to stories in the national press. In such a way, papers still command the nation's central political narrative" (Greenslade, 2011). The author states that such an activity is clearly seen in the periods between elections. Therefore, despite declining sales, the influence of the national press over the totality of the media agenda cannot be underestimated.

The most important content produced by the media is the news content and the public depends heavily on the media for the information about issues related to health, politics, environment, culture, business. Government molds the policies keeping in view of the issues that are important to the public and media plays a crucial role in determining what issues the public should think and worry about. Some scholars argue that the media has an iron grip on the thinking faculties of the masses and the "public may not know how deep the interlocking media reach into every phase of our lives, our reading, our viewing, our entertainment, our politics and our education" (klotzer, 2007). Media's power to frame public issues and to discursively construct messages that set public agenda is recognized by a range of academic research (Goffman, 1974; McCombs \& Shaw, 1972; Rogers \& Dearing, 1988).

The usage of the term discourse is common knowledge in sociology, linguistics, philosophy, and numerous other disciplines but the term is usually least defined and therefore it is interesting to trace the ways to make sense of the term. The general, philosophical and a new set of theoretical meanings of the term discourse began to diverge slightly during the 1960s. It is not easy to decide how or where to track down the meaning of the term discourse within the theoretical range of meanings (Mills, 1997). 
Collins dictionary describes discourse as 1) verbal communication; talk; conversation 2) a formal treatment of a subject in speech or writing 3) a unit of text used by linguists for the analysis of linguistic phenomena that range over more than one sentence 4) to discourse: the ability to reason (archaic) 5) to discourse on/upon: to speak or write about formally and extensively 6) to hold a discussion 7) to give forth (music) (archaic)

(Collins English Dictionary)

The very access to discourse and communicative events is the main factor in the discursive reproduction of power and dominance. For instance, in the political realm, cabinet meetings are accessible to ministers only and parliamentary debates to parliamentarians. In business corporations, only top businessmen have access to board meetings. In medical encounters, conversations between clients and doctors may be controlled by the doctors. Similar patterns of access exist also in education, media etc. In short, there is unequal access to media, medical, legal, political, bureaucratic or scholarly text and talk. Discourse is similar to other valued social resources in this respect, but the patterns of access to the mass media are the most significant and consequential because the opinions of the one interviewed, quoted and described in news reports will influence the masses. Therefore, those written or spoken about, i.e., the topics or referents of discourse may be studied to analyze the access (Van Dijk, 2008).

In some political systems dissent may be formally expressed by opposing politics while as in some politically repressive regimes, any form of dissent is suppressed or even prohibited. Dissent is a "crucial institution for challenging unjust hierarchies and for promoting progressive change" Shiffrin (1999). In the book, The First Amendment, Democracy, and Romance, Shiffrin (1990) define dissent as the "speech that criticizes existing customs, habits, traditions, institutions, or authorities."

\section{METHODOLOGY:}

This study undertook an analysis of discourse and dissent in Indian print media by analyzing the reportage of the blasts that occurred in the city of Hyderabad in India on February 21,2013 . It investigated the language used by the four leading Indian English. It explored different approaches adopted by the select newspapers and the difference in the reportage of the blasts. The parameter for selecting the newspapers is readership. According to the largest continuous readership research study in the world - The Indian Readership Survey (IRS) 2017, The Times of India, Hindustan Times, The Hindu and The Indian Express are the leading English dailies in India as per readership. Therefore the content produced by these newspapers reaches and hence affect masses.

In this study, intertextual analysis, framing, and a linguistic tool known as lexicalization is used to examine news reports (hard news and soft news) and news features. The placement and frequency of the attacks by the media were also analyzed. Analysis of the news reports is done followed by statistical interpretation.

The findings of the current study refer strictly to the news stories about the Hyderabad blasts that are covered by the select newspapers in 2013 i.e. editorials, and letters to the editor are not included in the sample.

\section{Hyderabad blasts}

Two blasts occurred in Hyderabad on 21 February 2013. Two bombs exploded in Dilsukhnagar area of Hyderabad one after the other killing 18 people and injuring about 131 people. The prime accused is Indian Mujahideen founder Riyaz Bhatkal.

\section{Analysis tools:}

Lexicalization: Lexicalization or word choice has prime importance in the studies involving critical discourse analysis. Lexical analysis is an important tool for textual analysis in critical discourse analysis. It determines whether the news report carry any ideological traces or is ideologically biased. The selection of word meaning through lexicalization is probably the major dimension of discourse meaning controlled by ideologies. Calling people terrorists instead of freedom fighters or vice versa is a well-known example of ideological language use. It is not just the nominal result of an evaluative categorization and identification but an ideological decision, depending upon the political position of the speaker or the group s/he belongs (Van Dijk, 1995).

Intertextuality: Bazerman (2004) explains intertextuality as, "the explicit and implicit relations that a text or utterance has to prior, contemporary and potential future texts." Intertextuality is the relation each text has to the texts around it. The relation of a statement to the words surrounding it and the way a statement uses those words and positions itself in respect to them is examined by intertextual analysis. How writers bring other characters into their story and their way of positioning themselves within the words can be learned by analyzing intertextuality. It reveals what sources the writer chose to build on and oppose. The ideas, research, and political positions behind policy documents can also be identified (Bazerman, 2004).

Framing: The basic premise of framing theory is that the way something is presented (the "frame") influences the choices people make. Frames are abstract notions which organise or structure social meanings. They can be considered cognitive shortcuts that are used by people to make sense of complex information. Frames are difficult to detect because many of the framing devices might appear as "natural", unremarkable choices of words and images. Such choices are central to the way news frames help to establish "common sense" (i.e., widespread) interpretation of events. Frames reside in the specific properties of the news narrative that encourages masses to develop a particular understanding of the events. News frames are constructed from and embodied in the keywords, metaphors, concepts, symbols, and visual images emphasized in a news narrative. Therefore frames can be identified by probing for particular words that appear in a narrative regularly.

\section{Content coded:}

The types of sources that are used in the news reports were identified and quantified to see how the text (direct quotes or paraphrased content) is used by the print media to shape other text (the text of the news story) and this is known as intertextuality. In this study, the sources used by the select newspapers are divided into five categories: victims, officials, eyewitnesses, anonymous and others.

1. The "officials" category includes government officials as well as the hospital authorities, official investigating agencies, police, and military. 
2. The "eyewitnesses" category includes those who witness the incident or experience the aftermath of the incident anyway.

3. The "victims" category includes those who are the direct victims of the attacks or who are victimized or have suffered due to the attacks in any way.

4. The "anonymous" category includes the sources used in the news stories that are not identified, unnamed sources, and those who wish not to be named/identified in the news reports.

5. The "other" category includes unattributed information or the sources used in the news reports that don't belong to any of the aforementioned categories.

To understand the pattern of narrative that is presented by the Indian print media, the keywords used in the news reports that fall into descriptive characterization are identified. 'Nominal characterizations' include 'words that label or describe the acts in a manner that merely indicates what happened. They are also words that label or describe the perpetrators, but with as little connotative meaning as possible' while as descriptive characterization include 'words that contain judgments about the acts or perpetrators within their denotative and connotative meanings' (Picard and Adams, 1991). The current study measured the descriptive characterization, i.e. the range of lexical choice opted by the select newspapers.

Frames can be identified in a text by recognizing "certain keywords, stock phrases, stereotyped images, sources of information, and sentences that provide thematically reinforcing clusters of facts or judgments" (Entman, 1993). Therefore, to detect the frames, specific words or phrases that are used by the Indian print media, in the reports about terrorist incidents, will be identified.

The analysis reveals that the following frames are often used in the news stories.

Public outrage: This frame highlights the reaction of the general masses and their sufferings due to the terrorist attacks.

Disaster frame: This frame highlights the damage done to the life and property by the terrorist attacks.

Pakistani terrorism: This frame talks about the alleged involvement of Pakistan in the terrorist activities in India.

Religious terrorism: This frame talks about the association of religion in the terrorist attacks.

Communal frame: This frame relates terror attacks to religious or ethnic lines.

Revenge frame: The frame portrays that the attackers are carrying out the attacks to avenge the loss that the members of their ethnicity or religion suffered.

\section{ANALYSIS AND FINDINGS}

The current study analyzed the placement, frequency and the frames in the news reports of the Indian print media regarding Hyderabad blasts.

\section{The frequency of stories:}

Table 1.1 represents the frequency of the media coverage of the terrorist attacks by the select newspapers

\begin{tabular}{|c|c|c|c|c|}
\hline News papers & The Times of India & Hindustan Times & The Hindu & The Indian Express \\
\hline Number of stories & 29 & 22 & 15 & 38 \\
\hline
\end{tabular}

Figure 1.1 is the graphical representation of the quantity of coverage of the terrorist attacks by the select newspapers Number of Stories

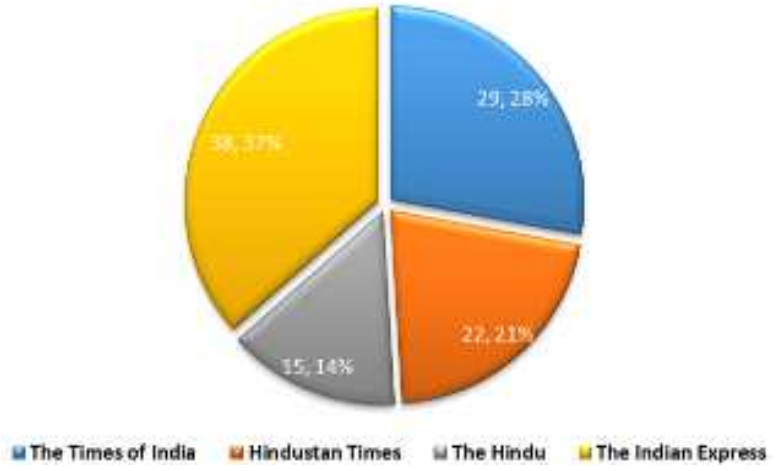

The study revealed that among the select newspapers, Hindustan Times gave the least coverage of $22 \%$ to the Hyderabad blasts while as The Indian Express gave the highest coverage of 38\%. The Times of India and The Hindu gave $28 \%$ and $15 \%$ of the coverage respectively.

\section{INTERTEXTUAL ANALYSIS}

\section{Sources used:}

Quantification of sources is done by categorizing them into five types: victims, officials, eyewitnesses, anonymous sources and others.

Table 1.2 represents usage of the types of sources by the select newspapers

\begin{tabular}{|c|c|c|c|c|c|}
\hline News paper & Victims & Officials & Eyewitnesses & Anonymous & Other \\
\hline The Times of India & 1 & 24 & 01 & 12 & 0 \\
\hline Hindustan Times & 0 & 20 & 0 & 07 & 02 \\
\hline The Hindu & 1 & 14 & 2 & 00 & 00 \\
\hline The Indian Express & 05 & 31 & 05 & 06 & 02 \\
\hline
\end{tabular}


Figure 1.2 is the graphical representation of the dominance of sources used in the news stories about the terrorist attacks.

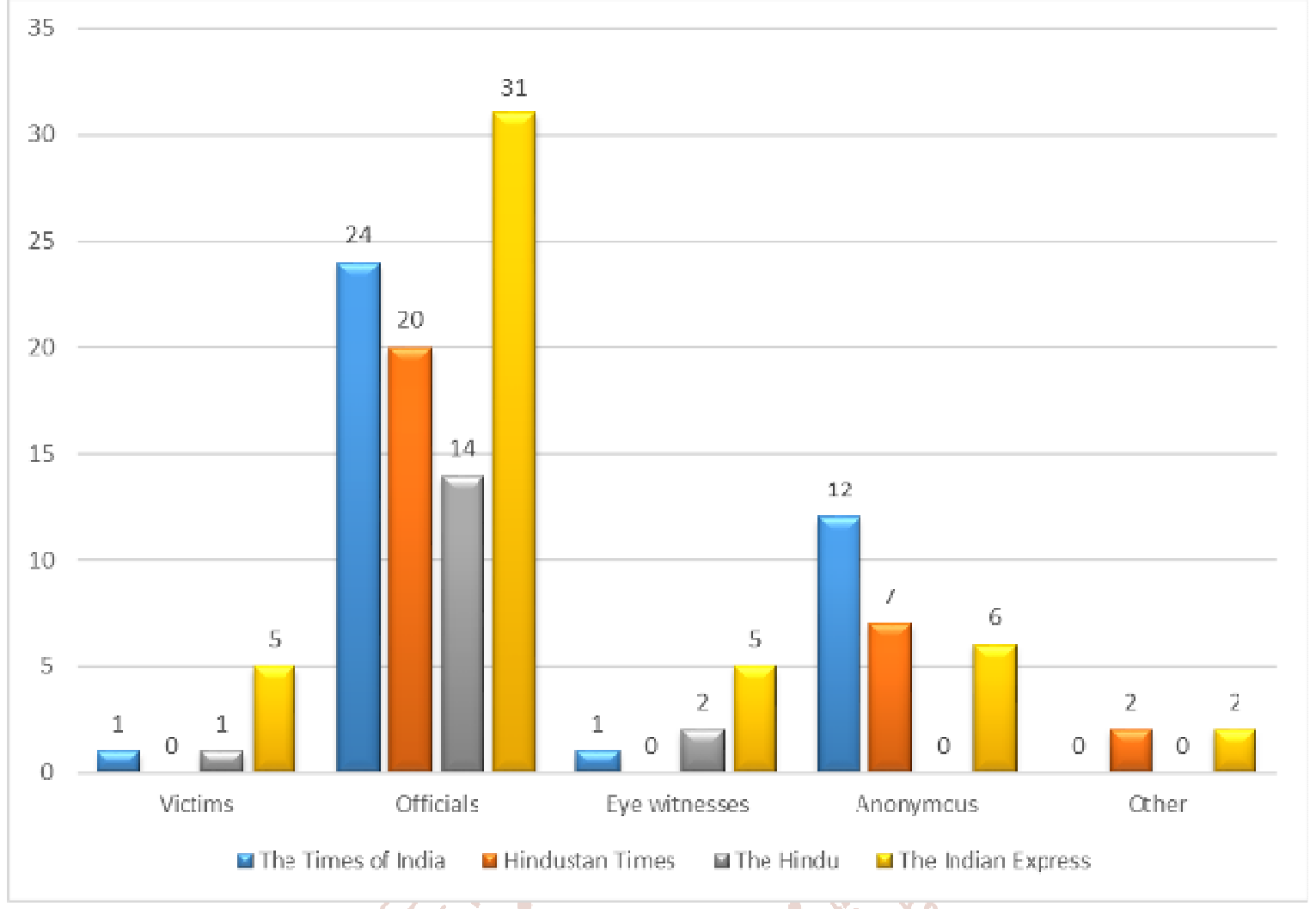

The study found a maximum number of stories in all the newspapers fall under "official" category of source classification and the least number of stories in all the newspapers fall under "other" category followed by the "victims" and then the "eyewitnesses" category, meaning the select newspapers depended heavily on the official sources.

Figure 1.3 Percentage-wise chart of the dominance of sources in the Times of India

\section{The Times of India}

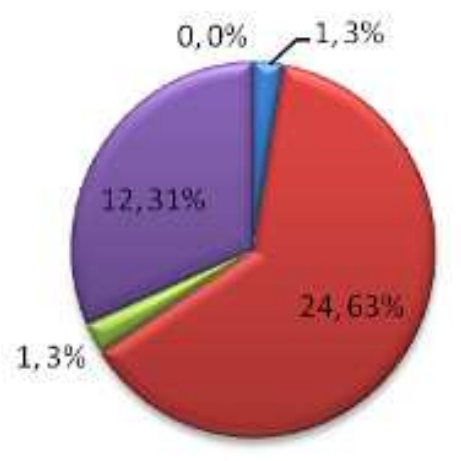

in Victims

Dofficials

Eyewitnesses

Anonymous

四 Other

Figure 1.4 Percentage-wise chart of the dominance of sources in the Hindustan Times

\section{Hindustan Times}

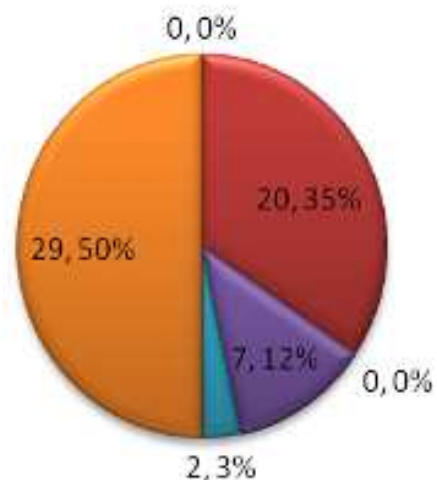

Q Victims

묘 Officials

Eyewitnesses

Anonymous

ather

u Total 
Figure 1.5 Percentage-wise chart of the dominance of sources in The Hindu

\title{
The Hindu
}

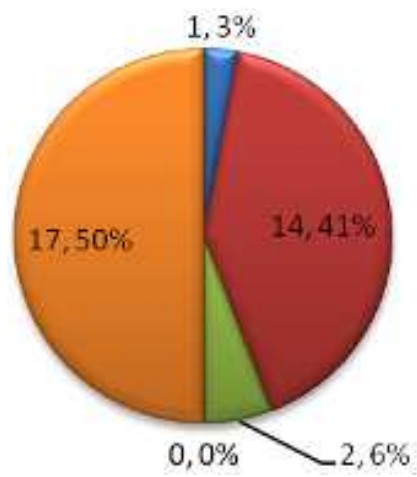

\author{
Victims \\ BOfficials \\ Eye witnesses \\ Anonymous \\ other \\ a Total
}

Figure 1.6 Percentage-wise chart of the dominance of sources in The Indian Express

\section{The Indian Express}

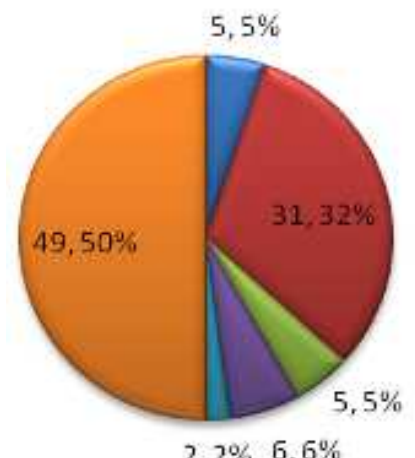

Victims

口officials

Eye witnesses

anonymous

$\square$ Other

B Total

\section{$2,2 \% 6,6 \%$}

The select newspapers have 63, 35,41 and 31 percent of their respective stories falling in the "officials" category and a fair percentage the sources that fall under the "anonymous" category but a very small percentage of their stories fall under "other", "victims" and "eyewitnesses" category.

\section{References used:}

The references used in the news reports are counted and each reference is given the value of one and then the comparison between the select newspapers is drawn to reveal which among them has used more references.

Table 1.3 represents usage of the references by the select newspapers

\begin{tabular}{|c|c|c|}
\hline Newspapers & No. of news reports & References used \\
\hline Times of India & 29 & 26 \\
\hline Hindustan Times & 22 & 14 \\
\hline The Hindu & 15 & 8 \\
\hline Indian Express & 38 & 21 \\
\hline
\end{tabular}

Figure 1.7 is the graphical representation of the usage of the references in the news stories

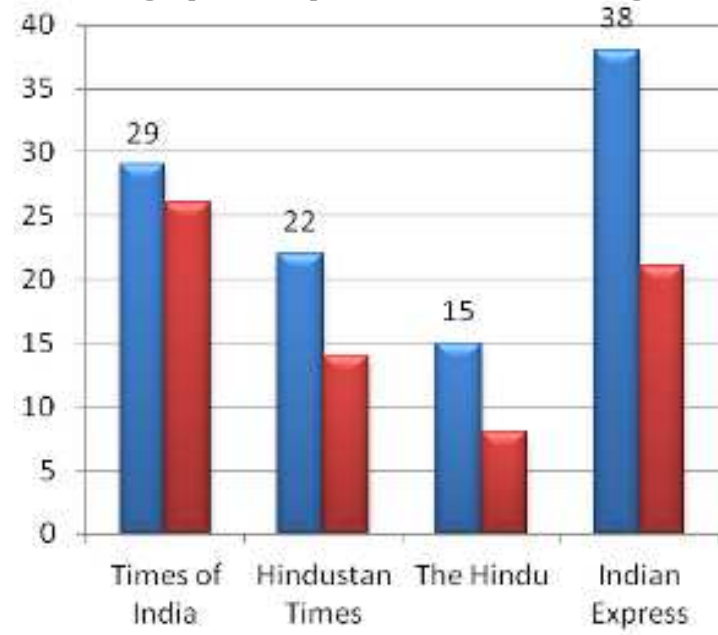

No. of news reports

a References used 


\section{References used}

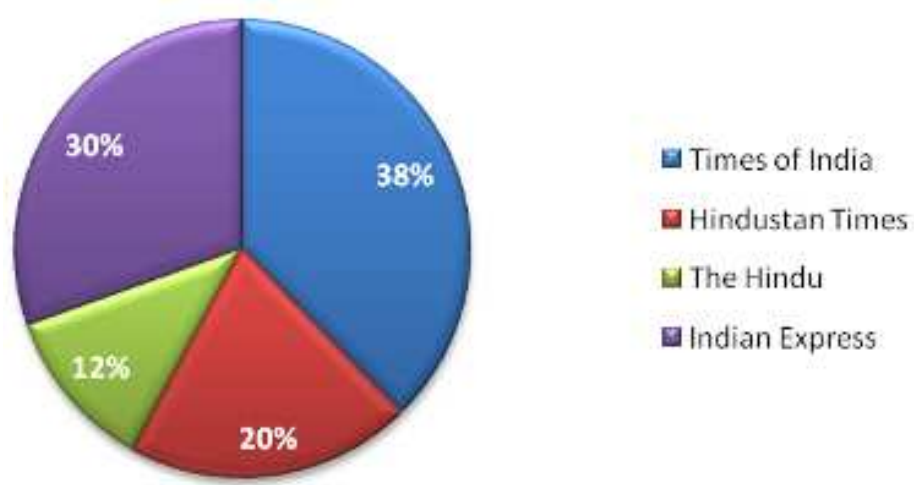

The chart shows that the maximum percentage of references are used by The Times of India (38\%), followed by The Indian Express (30\%), and Hindustan Times (20\%). The least percentage of references is used by The Hindu (12\%). The analysis reveals that among the select newspapers, The Times of India has evoked the incidents of the past in the news stories to the maximum and The Hindu to the minimum.

\section{Placement of the news stories}

The prominence given to the attacks by the Indian print media is evaluated by quantifying the number of news stories on the front page. Each front page story is given the value of 1 and then the comparison is drawn between the select newspapers. More the number of stories on the front page more is the prominence given to the attacks.

Table 1.4 shows the front page coverage given by the select newspapers to the Hyderabad blasts

\begin{tabular}{|c|c|}
\hline Newspapers & Front page \\
\hline Times of India & 6 \\
\hline Hindustan Times & 4 \\
\hline The Hindu & 4 \\
\hline The Indian Express & 9 \\
\hline
\end{tabular}

Figure 1.9 depicts the front page coverage given by the select newspapers to the Hyderabad blasts

\section{Front Page Coverage}

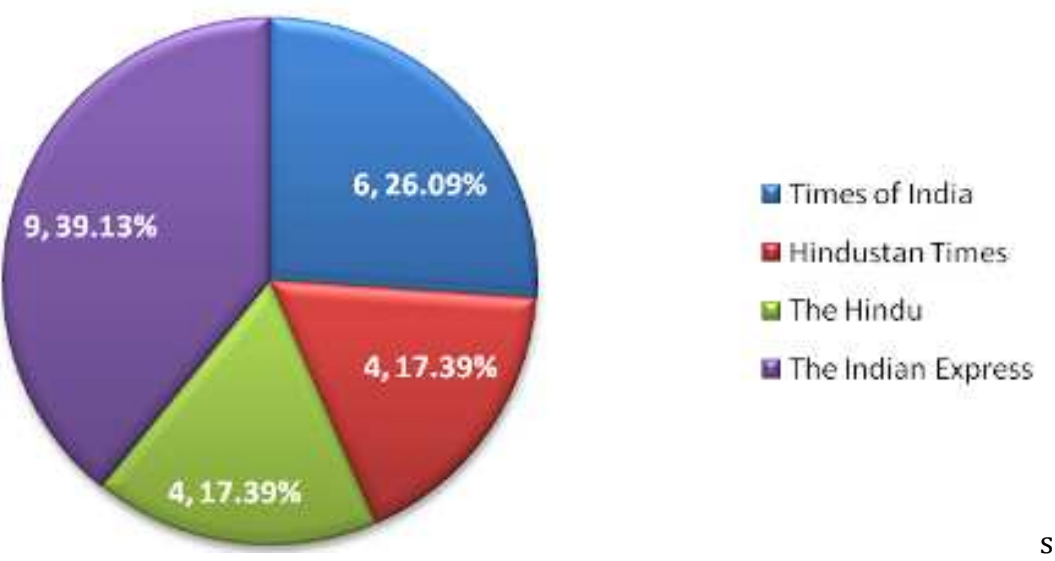

Figure 1.9 depicts that the percentage of the front page news items is more in The Indian Express (39.13\%), followed by The Times of India (26.09\%). Hence The Indian Express has given more prominence to the Hyderabad blasts while as Hindustan Times (17.39\%) and The Hindu (17.39\%) has given equal prominence to the news items about this particular attack.

\section{Classification of Discourse:}

The current study measures the descriptive characterization to reveal the discourse of dissent in the Indian print media. The keywords are identified and for quantification purpose, the value of 1 is given to each of them every time they are used in the news stories.

\section{Lexicalization}

Times of India carried stories having descriptive characterization greater in number while as The Indian Express has the lowest. 
Table 1.5 shows the keywords/phrases used in the news reports by the select newspapers. Keywords/phrases

dastardly attack, "federal crimes, terror-related cases", terror outfits, bloodaid, Terrified people, Pakistan-based terrorist group, terrorists , terror attacks, terror incident, terror in cidents, terrorist menace, terror crimes, terrorism, Pakistan's proxy war against India, terrorism being sponsored from across the border, terrorist attack, terror strikes, "highly-disturbed" crime scene, terror outfit, terrorist group, twin terror, Muslim populated regions, bomber, IED trainer, terror module, terror plans, terror hit, bombers, terror operations, LeT- SIMI sympathisers, one-man sleeper cell, terror plots, terror training, terror suspects, Jihad, banned terror outfit, IM terrorists, a Hindu-dominated locality, terror campaign, communal tension, communally sensitive areas, terrorist reprisal, cycle of terror, Islamic terrorism, innocuous religious platforms, start to finish jihad factory, emotive 'taqrirs' (speech), attitude hardening 'dars' (lessons), brainwashing, terror teams, terror organisations, militants, terrorist organisations, terror investigations, sleeper cells, faces of terror, IM-type bombs, financing terror, terror activities, Hindutva radicals

Table 1.6 shows the number of descriptive characterization used in the news reports by the select newspapers

\begin{tabular}{|c|c|}
\hline Newspapers & Descriptive characterization \\
\hline The Times of India & 35 \\
\hline Hindustan Times & 26 \\
\hline The Hindu & 21 \\
\hline The Indian Express & 17 \\
\hline
\end{tabular}

Figure 1.10 is the graphical representation of the comparison of the descriptive characterization used in the select newspapers

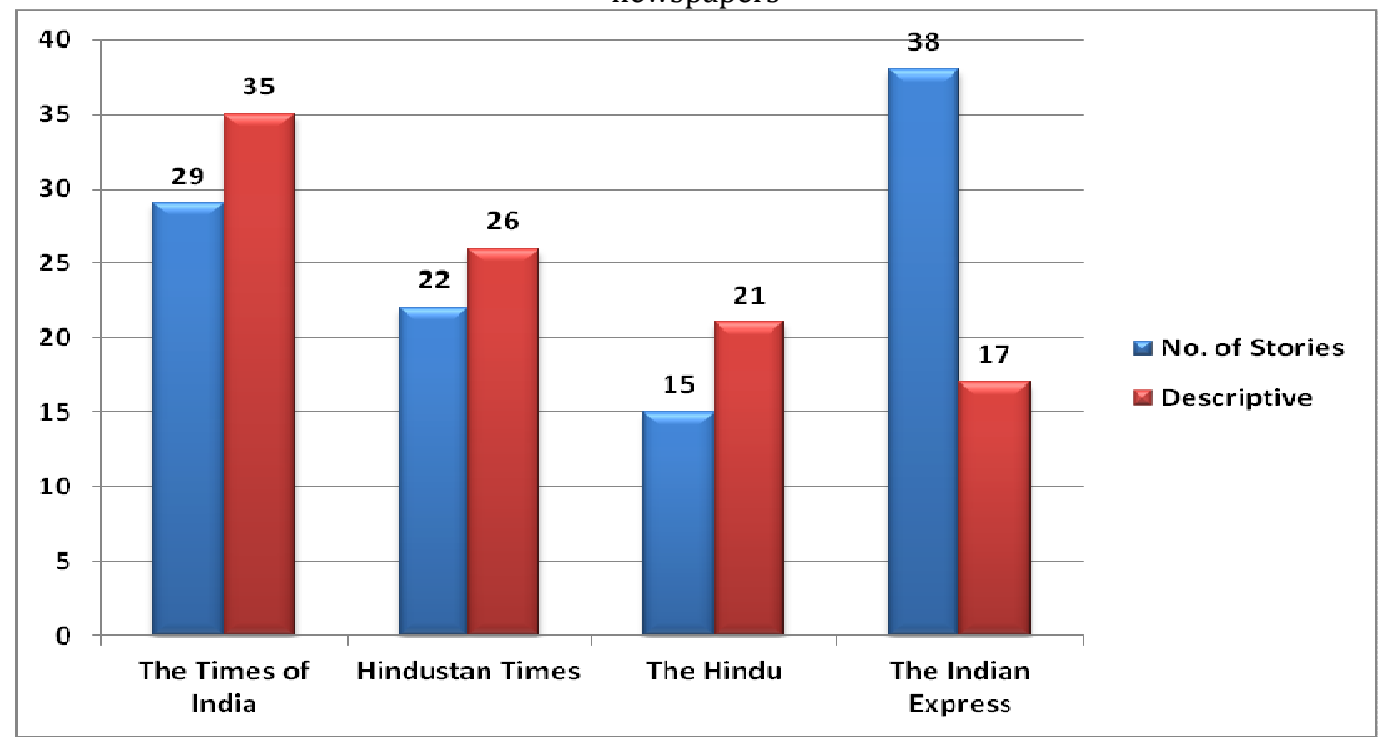

The analysis shows that The Times of India has the maximum number of stories having keywords that fall into the descriptive characterization, followed by Hindustan Times, The Hindu and The Indian Express has the lowest number of stories having keywords that fall into descriptive characterization.

Figure 1.11 shows the comparison of the percentage of the stories with descriptive characterization

\section{Percentage}

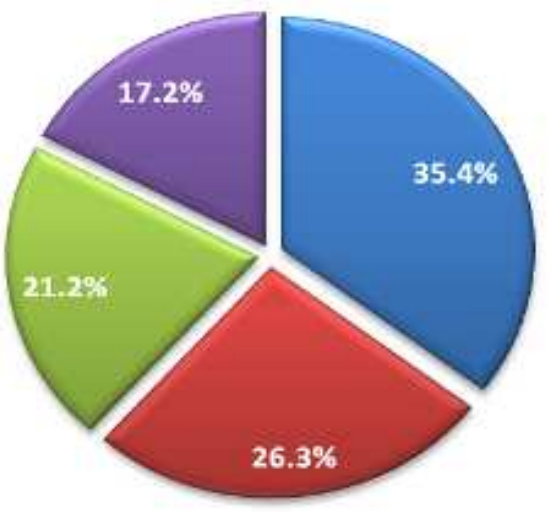

The Times of India $\mathbf{r i n d u s t a n}$ Times $\mathbf{a}$ The Hindu $\square$ The Indian Express 
In terms of the percentage, the narrative highlighted in the news reports carried by The Times of India (35.4\%) was mostly descriptive in nature followed by Hindustan Times (26.3\%) and The Hindu (21.2\%) i.e. the word choice is connotative in nature and naturally carries negative associations with them. The Indian Express carried $17.2 \%$ of the keywords which is clearly fairly less compared to other newspapers that are analyzed. Therefore the analysis of the select newspapers shows that the narrative is not completely pushed in one direction, which means that dissent is not stifled in the Indian print media vis-a-vis the coverage of the Hyderabad blasts.

\section{Framing:}

The current study identifies the following frames: Indo-Pak relations, public outrage, Pakistani terrorism, religious terrorism, disaster frame, revenge frame, and communal frame.

Table1. 7 shows that the most frequently used frame by the select newspapers

\begin{tabular}{|c|c|c|c|c|}
\hline Frames & The Times of India & Hindustan Times & The Hindu & The Indian Express \\
\hline Pakistani terrorism & 2 & 3 & 3 & 2 \\
\hline Religious terrorism & 3 & 1 & 0 & 1 \\
\hline Communal frame & 1 & 1 & 0 & 3 \\
\hline Disaster frame & 4 & 3 & 4 & 3 \\
\hline Revenge frame & 2 & 0 & 0 & 0 \\
\hline
\end{tabular}

The table1.7 shows that the most frequently used frame by The Times of India and The Hindu is the Disaster frame. Hindustan Times has used Pakistani terrorism and Disaster frame the most while as The Indian Express has used Communal and Disaster frame the most. The revenge frame is only used by The Times of India while has Religious terrorism and Communal frame is not used by The Hindu. The frame used most by the select newspapers is the Disaster frame followed by Pakistani terrorism which shows that the most emphasis is put on the damage done by the attacks to the life and property and then Pakistani hand in such attacks is emphasized.

The way masses understand the events depend on how the news event is covered by the media. Receivers of the news process the information provided by the media, interpret it and build their opinion. In addition to communicating to the world what it does, a media discourse also helps people to construct an image of what media discusses. There is not just one way to construct images. It is a complex process which includes some significant elements like the experience of individuals and the support of peers to anticipated image construction.

\section{References:}

[1] Paulsen, D. J. (2002). Wrong Side of the Tracks: Exploring the Role of Newspaper Coverage of Homicide in Socially Constructing Dangerous Places. Journal of Criminal Justice and Popular Culture, 9(3) 113-127. ISSN 1070-8286. Retrieved at 9.12 PM IST from http://www.albany.edu/scj/jcjpc/vol9is3/paulsen.ht $\mathrm{ml}$ on 19 January 2017

[2] Baum, M. And Groeling, T. (2009). War Stories: The Causes and Consequences of Public Views of War. Princeton: Princeton University Press.

[3] Greenslade, R. (2011). How newspapers, despite decline, still influence the political process. The Guardian. Retrieved at 9.12 PM IST on 17 January 2017 from https://www.theguardian.com/media/greenslade/201 1/jun/21/national-newspapers-newspapers

[4] Klotzer, C. (2007). Is it too late for media reform? St. Louis Journalism Review, 38(294), 28-29.
[5] Goffman, E. (1974). Frame analysis: An essay on the organization of experience. New York: Harper \& Row.

[6] McCombs, M. E. \& Shaw, D. (1972). The agenda-setting function of mass media. Public Opinion Quarterly, 36, 176-187.

[7] Rogers, E. \& Dearing, J. (1988). Agenda-setting research: Where has it been, where is it going? Communication Yearbook, 11, 555-594

[8] Sara Mills (1997), Discourse, The New Critical Idiom, Second Edition, Routledge, Taylor \& Francis Group.

[9] Van Dijk, T. A (2008). Discourse, Power and Access. Retrieved at 9.12 PM IST on 14 July 2018 from https://pdfs.semanticscholar.org/e128/b29decb7fc87 e71be456e83ab0330c485aa4.pdf

[10] Steven H. Shiffrin (1999), (page 77 \& page 12) Dissent, injustice and the meanings of America. Princeton University Press, Princeton, New Jersey.

[11] Steven H. Shiffrin (1990), page 96. The First Amendment, Democracy, and Romance. Princeton University Press, Princeton, New Jersey.

[12] Van Dijk, T. A., (1995). Aims of critical discourse analysis. Japanese Discourse, 1, 17-27. Retrieved at 9.12 PM IST on 16 December 2017 from http://discourses.org/OldArticles/Aims\%20of\%20Crit ical\%20Discourse\%20Analysis.pdf

[13] Bazerman, C. (2004). Intertextuality: How Texts Rely on Other Texts. Retrieved at 9.12 PM IST on 17 June 2016 from https://www.researchgate.net/publication/31511247 9_Intertextuality_How_Texts_Rely_on_Other_Texts_1

[14] Picard, R.G. and Adams, P.D. (1991). 'Characterization of Acts and Perpetrators of Political Violence in Three Elite U.S. Daily Newspapers', Emerson College and California State University, Fresno. Retrieved at 9.12 PM IST on 12 January 2017 from http://files.eric.ed.gov/fulltext/ED312696.pdf

[15] Entman, R. M. (1993). Framing: Towards Clarification of a Fractured Paradigm. Journal of Communication, 43 (4), 51-58. Northwestern University. DOI: 10.1111/j.1460-2466.1993.tb01304.x 